\title{
SPRITUALITAS IBADAH DALAM TRADISI METHODIST DI TENGAH PANDEMI COVID-19
}

\author{
BONE PANDU WIGUNA \\ GEREJA METHODIST INDONESIA
}

pandubone@yahoo.com

\begin{abstract}
Worship is often understood as a time where people gain something good from God. It will lift up their spirituality and make their lives more blessed and cheerful. Worship in Hebrew abodah means to serve. Therefore worship means a time to do or to give something to God. Worship is the time to give rather than to gain. Focus of the worship in Methodist Church is not laid on the worship itself, but on the result. How the people can be changed after the service. Therefore after or in the end of sermon there is an "altar calling" Today evangelism can come alive through worship as it did in the past. Worship services must accur outside the walls of a church building. For evangelism does not nessesarily mean getting people into the church. The situation in Indonesia right now, facing the pandemic Covid-19 proof that the church must innovative in doing worship services. How does the church can change or innovate the liturgy for worship services. Worship God is not only in a church building, but also outside in words and action, helping the people in need.
\end{abstract}

Keywords : spiritual, worship, methodist, wesley, service

\begin{abstract}
ABSTRAK
Beribadah sering hanya diartikan sebagai kegiatan umat untuk mendapatkan berkat dari Tuhan. Ibadah di gereja akan mengangkat kerohanian mereka dan memberi harapan yang lebih menyenangkan dalam kehidupan mereka. Ibadah yang berasal dari kata abodah, berarti melayani, memberikan sesuatu kepada Tuan (Tuhan) yang sudah lebih dulu bertindak. Jadi ibadah merupakan jawab manusia atas tindakan Allah yang terlebih dulu berfirman, bertindak, dan memberi kepada manusia. Beribadah merupakan saat memberi bukan menerima. Fokus dalam Gereja Methodist adalah hasil dari ibadah itu sendiri dan bukan pada peristiwa atau tindakan ibadah itu saja. Itu sebabnya pada akhir khotbah hampir selalu dilakukan "Altar Calling" ("Panggilan Kemuridan"). Saat ini penginjilan dapat menjadi hidup melalui ibadah seperti yang terjadi di masa lalu. Ibadah harus terjadi diluar dinding-dinding bangunan Gereja. Ibadah harus akurat di luar tembok gedung gereja. Karena penginjilan tidak harus berarti membawa orang ke gereja. Situasi di Indonesia saat ini, menghadapi pandemi Covid-19 bukti bahwa gereja harus inovatif dalam melakukan ibadah. Bagaimana gereja dapat mengubah atau berinovasi dalam liturgi untuk kebaktian. Menyembah Tuhan tidak hanya di gedung gereja, tetapi juga di luar dalam kata-kata dan tindakan, membantu orang-orang yang membutuhkan.
\end{abstract}

Kata Kunci : spiritualitas, ibadah, methodist, wesley, pelayanan.

\section{Pendahuluan}

Beribadah sering hanya diartikan sebagai kegiatan umat untuk mendapatkan berkat dari Tuhan. Ibadah di gereja akan mengangkat kerohanian mereka dan memberi harapan yang lebih menyenangkan dalam kehidupan mereka. Fokus dalam ibadah bukan Tuhan yang disembah, melainkan seseorang dalam abodah itu sendiri. Bisa jadi itu adalah pengkotbahnya atau seseorang yang hadir dalam ibadah itu. Tiap orang yang ambil bagian dalam ibadah berusaha agar orang itu menenangi ibadah yang mereka lakukan.

Hal ini tentu saja membuat Tuhan yang disembah dalam ibadah hanya sebagai "Tamu" dan bukan sebagai "Tuan". Ada banyak ibadah tidak memberi dampak positif dalam kehidupan sehari-hari 
mereka yang beribadah. Ibadah dilakukan hanya sebagai rutinitas tanpa arti atau hanya sekedar memberi semangat baru seperti satu baterai yang diisi ulang lagi.

Tulisan ini mencoba meneliti arti ibadah itu dan kaitannya dengan perkembangan ibadahibadah dalam Methodist Movement yang terjadi di Inggris. Gereja Methodist Indonesia yang mengikuti tradisi Wesley apakah masih memiliki semangat dan jiwa Wesleyan itu.

\section{Pengertian Ibadah}

Istilah Ibadah berasal dari kata abodah yang berarti pelayanan. (Ralph P. Martin, Worship in the Early Church, (Grand Rapids: W.B. Eedmans Publishing Company, 1976), hal.11-12) kata ini mempunyai akar kata yang sama dengan ebed, pelayan atau hamba. Pengertian ini penting, sebab penandaan yang paling cocok dalam bahasa Ibrani dalam kaitan dengan ibadah kepada Allah adalah kata "hamba" atau ebed. Raja Daud senang menyebut dirinya sebagai "Hamba Allah" (Maz. 116:16), dan orang Israel menyebut Daud, Rajanya sebagai hamba. Peraturan itu menunjukkan suatu hubungan yang khas antara budak dengan tuannya. Ada kerelaan dari pihak budak untuk tetap mengabdi kepada tuannya. Hal ini menunjukkan relasi antara manusia dengan Allah. Manusia sebagai hamba mempunyai "kebebasan" untuk menentukan jalan hidupnya sendiri, apakah akan tetap mengabdi kepada tuannya atau bebas dari tuannya. Relasi inilah yang Rasul Paulus utarakan dalam suratnya (Roma 1:9; 12:1; 15:16). Bagi Paulus adalah suatu kehormatan dan karunia apabila dapat "melayani" dan "beribadah"kepada Allah. Evelyn Underhill menggambarkan ibadah dalam dua cara. (Evelyn Underhill, Worship, (London: Nisbet \& Co.Ltd., 1948), hal.3) Dia mendefinisikan ibadah sebagai the response of the creature to the eternal, atau dapat juga dikatakan, an acknowledgment of God as transcendent. Penekanan Allah yang kekal dan transenden, yaitu "diatas" dunia dan menempati ruang yang disebut "suci", menyebabkan ibadah Kristen sulit menyampaikan sesuatu yang bermanfaat bagi masyarakat pada tahun 1900an (R.P.Martin, The Worship of God, (Michigan: W.B. Eerdmans Publishing Company, 1984), hal.3).

Rudolf Otto lewat bukunya The Idea of the Holy (1923), menganalisa elemen misterius dalam pengalaman keagamaan, telah menghantar dia pada suatu usulan, bahwa ibadah adalah suatu creaturely feeling in the presence of Deity (ibid). Dijelaskannya, Allah adalah yang kudus; manusia merasakan ketidakpastian dan kelemahannya pada saat diperhadapkan pada kemahakuasaan dan kemahakudusan Allah. Martin menyimpulkan, ibadah adalah suatu perayaan yang dramatis dari Allah dalam kekayaan dalam suatu cara tertentu sehingga kekayaan-Nya menjadi kaidah dan inspirasi bagi manusia. (ibid, hal.4). Dari definisi ini dia pertama-tama menempatkan Allah pada "pusat Ibadah" dan menekankan theologia tentang ibadah; "kita beribadah sebab Allah harus disembah". Keberadaan manusia adalah untuk memuliakan Tuhan. Aksi social, pendidikan dan peningkatan taraf ekonomi harus ditempatkan pada perspektif yang benar. Semua ini harus dipandang sebagai usaha untuk memuji dan memuliakan Allah, sebagai suatu aksi nyata dari ibadah. (T.S. Garret, Christins Worship, An Introducyion Outline (Bedford: Oxfor University Press, 1959), hal.3).

Kedua, menurut Martin (Op.cit.,hal.5), defenisi yang pertama tadi akan menghindarkan kita dari ketidak sewenang-wenangan subyektivisme (tyranny of subjectivism). Banyak orang mengharap, bahwa ibadah gereja akan mengangkat kerohanian mereka dan memberi harapan yang lebih menyenangkan dalam kehidupan mereka. Hal-hal ini bukanlah menjadi tujuan dari ibadah. Tujuan utama dari adalah Allah sendiri.

Ketiga, ibadah dilangsungkan untuk dan kepada Allah (ibid., hal.6.). ibadah dilakukan oleh mereka yang semangatnya atau rohnya dicerahkan untuk menerima kesan-kesan Allah yang mereka sembah. Satu hal yang amat menarik dan penemuan kembali amat penting pada saat ini adalah bentuk dialog dalam ibadah Kristen. Dalam ibadah jelas terlihat adanya dua detak irama pernyataan dan 
jawab atas pernyataan itu. Allah berbicara, manusia menjawab; Allah bertindak, manusia menerima dan memberi; Allah memberi manusia menerima. Demikian Juga Abineno (J.L.Ch.Abineno, Gereja dan Ibadah Gereja, (Jakarta: BPK Gunung Mulia, 1986), hal.2.) memberi arti, bahwa ibadah ialah suatu pertemuan antara Allah dan Jemaat. Dalam pertemuan ini berlangsung semacam "dialog". Lebih lanjut dijelaskannya, karena dialog ini adalah dialog antara Allah dan Jemaat, maka Pendeta tidak boleh mengambil alih tugas Jemaat. Jemaat sendiri yang harus menjawab, menyanyi, memuji, dan mengucap syukur.

Jadi ibadah merupakan jawaban manusia atas tindakan Allah yang terlebih dulu berfirman, bertindak, dan memberi kepada manusia. Dalam peristiwa dan pertemuan itu ada dialog antara Allah dengan manusia. Ibadah tidak dibatasi oleh ruang tertentu atau waktu-waktu tertentu saja, misalnya di gedung gereja atau pada hari Minggu saja, tetapi seluruh keberadaan manusia haruslah merupakan ibadahnya kepada Allah (Band. Roma 12:1).

Ibadah adalah suatu proses dimana kita merayakankan dan menemukan kenyataan pada tingkat sedalam-dalamnya. (Kenneth Bedell, Worship in the Methodist Tradition, (Nashville: Tidings, 1976), hal.3) ibadah tidak dapat dipisahkan dari seluruh segi kehidupan gereja atau pengalamanpengalaman pribadi Kristiani. Setiap keputusan yang kita perbuat dipengaruhi oleh pengertian kita akan kenyataan. Kegiatan ibadah tidak dapat dianggap sebagai suatu waktu dimana kita seolah-olah mengisi kembali baterainya. (ibid).

Ibadah yang benar membuat kita merasa baik bukan karena kita telah menghindar dari kenyataan tetapi karena kita telah mengikuti dan menjadi mengerti akan kenyataan pada tingkat yang sedalam-dalamnya. Ibadah dapat membantu kita menghadapinya dan mengatasi kesukaran-kesukaran dari dunia ini.

Ibadah harus peka terhadap perubahan yang terjadi tentang kenyataan hidup dan perubahan pandangan-pandangan manusia. Ini bukan berarti hanya memodernkan bahasa ibadah, walau itu tentunya juga penting, atau "mengikuti arus", "mengikuti trend mode". Ibadah haruslah bersangkutpaut dengan keadaan nyata dalam hidup ini.

Ibadah dapat menjadi sumber untuk pembaharuan gereja. (ibid, hal.5) pengalaman beribadah dapat merupakan saat untuk mengkomunikasikan isi dari pengajaran Alkitab kepada kenyataan keseharian kita. Kita harus selalu bertanya: "sampai dimana tatanan pesan ibadah konsisten dan konsekwen dengan ajaran Kristiani?" dan "bagaimana baiknya ajaran kristiani itu dikomunikasikan dalam ibadah?" tidak cukup dalam ibadah itu hanya konsisten dengan ajaran Alkitab, tetapi bagaimana mengkomunikasikannya kepada Jemaat yang hadir dalam situasi mereka masing-masing.

Dunia sekular menawarkan bentuk-bentuk kesenian, bahasa dan cara-cara berkomunikasi yang dapat membantu.Tentu saja cara-cara ini harus dipertimbangkan dengan matang dalam merancang suatu ibadah. Janganlah kita mengabaikan kekayaan sumber-sumber tradisi dalam ibadah. Tradisi ibadah dapat memberikan kilas balik yang dapat memperkaya pengalaman-pengalaman beribadah. Akan tetapi kita harus waspada, jangan sampai seperti yang dikatakan pepatah Perancis, "Kita harus berhati-hati dalam membawa dari masa masa lalu kobaran api dan bukan abunya." Ada keterbatasan dalam penggunaan tradisi ibadah Methodist. Methodisme pada hakekatnya dapat dikatakan sebagai suatu gerakan pembaharuan liturgi. (Ibid, hal.2)

\section{Ibadah Dalam Tradisi Methodist}

Ibadah yang diperkenalkan Wesley adalah untuk mendukung dan merangsang pembaharuan. Ibadah Methodist Amerika pada awalnya dibentuk untuk memenuhi kebutuhan gerakan Methodisme ketimbang membentuk suatu gereja. Jika kaum Methodist membatasi dirinya hanya menjalankan ibadah menurut tradisinya saja, maka mereka tidak akan mendapatkan potensi untuk adanya 
pembaharuan. Memperbaiki keindahan atau kemurnian dari kebaktian ibadah saja bukanlah tujuan. Pembaharuan ibadah dan pembaharuan pribadi dan gereja harus berlangsung sejalan dengan bergandengan tangan.

Sumbangasih John Wesley pada ibadah adalah sangat besar dan baik. Ia tidak mencoba untuk mengubah secara besar-besaran ibadah Inggris, namun ia mendukung perubahan-perubahan yang timbul yang mengubah baik bentuk maupun maksud dari ibadah. Sifatnya konservatif, digabung dengan semangat menyebarkan ajaran agamanya menghasilkan perubahan-perubahan dalam liturgi kebaktian maupun memperkenalkan sejumlah bentuk baru dari ibadah di Inggris. Horton Davies, seorang sejarahwan liturgi di Inggris, mengamati, bahwa John Wesley menghargai liturgi dan Ekaristi dalam tradisi gereja Anglikan. (Dikutip dari Ibid, hal.11) Tetapi dia, walaupun pada mulanya agak terpaksa, akhirnya mengakui nilai-nilai praktis khotbah spontan, doa bebas dan nyanyian pujian. Inilah sumbangasih Wesley yang terpenting dalam sejarah keKristenan di Inggris pada abad 18 tentang liturgi gereja.(Ibid)

\section{Khotbah}

Khotbah merupakan bagian yang diabaikan dalam liturgi kebaktian Gereja Inggris. Kebanyakan khotbah yang ada sangat kurang bermutu baik isi maupun cara penyampaiannya. Itu sebabnya khotbah tidak mempunyai pengaruh pada kehidupan bangsa dan pribadi. Umumnya mereka ke Gereja untuk sakramen. Khotbah-khotbah yang ada kebanyakan disiapkan untuk diterbitkan dan tidak pernah dibawakan dari atas mimbar. Kebanyakan orang-orang Inggris dibaptis di Gereja, menikah di situ dan juga dikuburkan oleh pendeta-pendeta Anglikan, tetapi mereka menjalani kehidupan tanpa sekalipun mendengarkan suatu khotbah.

Khotbah-khotbah Wesley seringkali bersifat doktrinal dan pada kesempatan lain etis, tetapi selalu penuh dengan semangat dan kesungguhan. Saksi-saksi mata menyatakan, bahwa Wesley adalah seorang pembicara yang sangat meyakinkan. John Wesley tidak mengarang atau memuat suatu buku yang berisikan pemikiran atau doktrin-doktrin yang diajarkan. Hampir semua "Pengajaran atau doktrin Wesleyan" itu terdapat dalam khotbah-khotbahnya. (Selain dalam kotbah, juga dapat dilihat dalam jurnalnya)

John Wesley mempopulerkan khotbah-khotbah spontan di Inggris, suatu corak yang akan menjadi "ciri khas" (trade mark) pendeta-pendeta Methodist Amerika. Pada mulanya, Wesley yang terdidik di Oxford merasakan ketidaknyamanan berkhotbah tanpa naskah atau catatan-catatan, tetapi ketidak-mungkinannya mempersiapkan naskah-naskah, sedangkan jadwal berkhotbahnya seringkali mengharuskan dia berkhotbah rata-rata lebih dari satu khotbah dalam sehari. Keadaan inilah yang memaksa dia harus melakukan khotbah spontan.

Khotbah-khotbah spontan Wesley sangat sedikit yang dapat kita ketahui. Referesi jelas pertama yang ada tentang khotbah spontan dapat ditemui dalam Journal, terbitan 28 Januari 1776 yang mengacu pada suatu kebaktian pada tahun 1735. Wesley menulis,'Ini adalah pertama kalinya dimana tanpa catatan-catatan, saya berkotbah secara spontan tanpa persiapan". Ini menunjukkan, walau tidak membuktikan, bahwa Wesley seringkali berkhotbah tanpa persiapan sejak tahun 1735 . Bukti selanjutnya adalah kenyataan, bahwa khotbah-khotbahnya yang diterbitkan tampaknya ditulis secara khusus untuk diterbitkan. Itu bukanlah salinan naskah-naskah daripada di mana ia berkhotbah.

\section{Doa Bebas/Spontan}

Sumbangasih lainnya yang diberikan Wesley dalam hal liturgi Gereja Inggris adalah doa-doa yang diucapkan secara spontan. Berdoa secara bebas menjadi bertambah penting baginya seiring 
makin bertambahnya usia. Ironisnya, waktu masih kuliah, Wesley sangat menentang doa-doa bebas. Ia merasa bahwa doa harus tersusun secara cermat dan ia menuliskan serangkaian doa-doa yang khusus diperuntukan bagi pribadi-pribadi, keluarga dan anak-anak. Doa-doa ini diterbitkan sewaktu ia berada di Oxford sebelum pergi ke Georgia. Doa-doa ini memperhatikan tentang dosa dan kejahatan, tapi tidak menyebut tentang dosa asal. Doa-doa untuk keluarga dan anak-anak tidak terlampau menekankan tentang dosa tetapi lebih menekankan akan kesadaran atas kasih Allah.

Ketika Wesley berada di Georgia dia mengucapkan doa-doa spontan. Pada tahun 1786 ia tidak lagi merasa harus meminta maaf jika mengucapkan doa-doa spontan. Wesley mengakui juga tentang pengaruh dari kaum Puritan tentang hal ini. Dalam suatu penjelasan tentang Methodist ia pernah menulis, "Walau kita sering menggunakan doa-doa spontan, dan berkumpul bersama di dalam suatu kelompok beragama; tetapi kita bukanlah kelompok yang berbeda pendapat. "Pada penghujung hidupnya, Wesley sangat menganjurkan penggunaan doa-doa spontan, baik sebagai bagian dari liturgi maupun dalam keadaan-keadaan lainnya. Kita tidak mengetahui apa isi dari doa-doa spontan Wesley.

Wesley tidak mengesampingkan digunakannya doa-doa yang dipersiapkan sebelumnya, juga tidak mengusulkan agar doa-doa spontan menggantikan semua doa-doa yang terdapat di dalam The Book of Common Prayer/Kumpulan Doa-Doa Umum. Ia hanya menambahkan berdoa secara spontan didalam ibadah Gereja Anglikan. Pada bagian akhir dari bukunya The Sunday Service of the Methodist in North America, yang merupakan suatu perbaikan atas kebaktian seperti yang tercantum dalam bukunya The Book of Common Prayer. Wesley menambahkan, "Kemudian Penatua, jika ia merasa bahwa itu diperlukan, dapat mengucapkan suatu Doa Spontan." Berdoa secara spontan dianggap begitu lumrahnya oleh kaum Methodist Amerika awal sehingga dalam Discipline terbitan tahun 1798 tercantum peringatan: "Janganlah berdoa secara ex tempore/tanpa catatan diatas delapan atau sepuluh menit (maksimal) tanpa melakukan selingan." Dalam penjelasan atas bagian tersebut dari Discipline, Bishop Asbury dan Coke berkata, "Hampir tak ada yang mengganggu didalam suatu kebaktian yang khidmat kecuali doa yang berkepanjangan yang diucapkan tanpa semangat." Doa spontan merupakan suatu ciri khas dari pendeta-pendeta Methodist Amerika.

\section{Nyanyian Pujian}

Wesley juga memberikan sumbangsihnya bagi perkembangan ibadat dalam bidang nyanyian pujian. Bersama adiknya Charles, Wesley sangat banyak menambahkan jumlah nyanyian pujian didalam kebaktian Inggris dan juga memperbaiki mutunya. Clifford Towlson, pengarang buku Moravian and Methodist, dengan yakin menyatakan, bahwa "John Wesley, bukannya Charles, yang menjadi pemula dalam perubahan bentuk dan semangat yang mengubahkan nyanyian pujian Inggris."Nyanyian pujian Wesley kebanyakan digubah untuk kebaktian ekaristi, tetapi juga untuk keadaan/situasi lainnya juga. Nyanyian pujian juga merupakan bagian dari kebaktian tempat terbuka, pertemuan kelas, perjamuan kasih, kebaktian semalaman (all night), kebaktian upacara pernikahan, maupun dalam perayaan Perjamuan Kudus.

Mungkin Wesley akan terperanjat bila ia mengetahui demikian banyaknya nyanyian pujian abad ke-18 yang masih dinyanyikan didalam abad ke-20 di kebaktian-kebaktian Methodist. Ia menggubah nyanyian pujian untuk keadaan-keadaan khusus dan jemaat-jemaat khusus. Wesley juga menggunakan nyanyian pujian menjadi alat mengajar dan alat untuk mengubahkan seseorang. Wesley menggubah nyanyian pujiannya sendiri, tetapi sumbangsihnya yang terutama adalah penterjemahan nyanyian pujian yang biasa dipakai di daratan Eropa.

Akan tetapi Wesley tidak terlalu menganjurkan penggunaan paduan suara dalam ibadah. Ia tidak menggubah nyanyian gereja untuk paduan suara. Dia berpendapat, jika nyanyian adalah untuk memuji Allah ia percaya bahwa itu harus dinyanyikan oleh seluruh anggota jemaat. Nyanyian pujian 
menjadi sesuatu yang mutlak dalam pengajaran Alkitabnya Wesley. Dengan jelas ia perlihatkan ini dalam kata pendahuluan yang ia tuliskan untuk A Collection of Hymns for the Use of the People Called Methodist (Kumpulan Nyanyian Pujian untuk digunakan bagi Orang-orang yang Menyebut Dirinya Methodist): "Nyanyian pujian .... Bukan dengan sembarangan dicampur-adukkan menjadi satu, tetapi disusun dengan cermat dibawah judul-judul yang sesuai, berdasarkan pengalaman sesungguhnya dari orang-orang Kristiani.Karena itu buku ini sebenarnya adalah suatu bentuk kecil dari pengajaran ketuhanan praktis dan eksperimental."(Ibid, hal. 17)

Jadi, John Wesley membuat dua sumbangsih dalam dibawakannya nyanyian pujian di Inggris abad ke-18. Pertama, ia menambahkan jumlah dan mutu dari nyanyian pujian. Kedua, ia mendorong penggunaan nyanyian pujian sebagai suatu penyataan theologia dan sebagai suatu sarana dalam menjalankan pengajaran Alkitabnya.

Bernyanyi merupakan suatu bagian penting dalam ibadah Methodist Amerika. Buku Discipline Amerika awal dari tahun 1798 mencantumkan agar jangan menyiksa jemaat dengan nyanyian yang bertempo terlampau lambat.

Uskup Asbury dan Coke menyarankan agar para pendeta menunjukkan kepada jemaat "pentingnya bernyanyi dan memerankan setiap bagian dari penyembahan dari dalam hatinya"

\section{Kesaksian}

Selain ketiga hal diatas, Wesley juga memperkenalkan acara kesaksian-kesaksian dalam ibadah tanpa dimasukkan dalam liturgi. Wesley meyakini bahwa pengalaman agamani setiap orang dapat dibagikan kepada orang lain. Kesaksian harus jelas-jelas dibedakan dari khotbah. Khotbah adalah Firman Allah; penyajian dan penerangan tentang Injil Allah. Kesaksian adalah pengertian tentang pengalaman Kristiani. Wesley tidak memasukkannya di dalam liturgi kebaktian (secara resmi/tertulis). Kesaksian seringkali terjadi secara spontan. Pengenalan kesaksian dalam ibadah Anglikan merupakan suatu langkah radikal.

\section{Tiga Bentuk Baru Ibadah}

John Wesley bukan saja mempengaruhi isi dan cara dari ibadah-ibadah di Inggris, ia juga memperkenalkan bentuk-bentuk baru dalam beribadah. Dari ketiga bentuk ibadah yang diperkenalkan Wesley di Inggris Kebaktian Larut Malam (Watch Night Service). Perjamuan Kasih (Love Feast Service) dan Kebaktian Perjanjian (Covenant Renewal Service). (Bagian ini lihat Bedell, Worship in the Methodist Tradition, hal.19-29)

Wesley pertama-tama melihat kebaktian Perjamuan Kasih ini ketika ia berada di Georgia. Kita tidak mengetahui secara tepat urutan liturgi kebaktian ini, tetapi di dalamnya ada acara makan roti dan minum air atau teh, kesaksian-kesaksian dan berdoa, membaca Alkitab dan nyanyian pujian. Mula-mula mereka menggunakan roti dan anggur dalam kebaktian-kebaktian ini, tetapi agar tidak terjadi kesalahpahaman dengan Ekaristi, mereka segera menggantikannya dengan teh dan sejenis roti yang khusus. Karena Perjamuan Kasih ini bukanlah suatu sakramen, maka dapat dipimpin oleh pengkhotbah-pengkhotbah warga.

Dalam Journal dikatakan, bahwa pada mulanya Perjamuan Kasih ini diperuntukkan bagi kaum wanita saja. Namun, kemudian, Wesley mengusulkan agar jamuan kasih ini diadakan tiga kali dalam suatu perempat tahun (semester), sekali untuk kaum Pria, sekali untuk kaum wanita dan sekali untuk kaum pria dan kaum wanita bersamaan. Pada akhir masa hidupnya, Perjamuan Kasih ini sudah tidak dijalankan lagi dan tak lama setelah meninggalnya, kebaktian ini dihentikan di Inggris. Pada 
masa sekarang perjamuan kasih dilakukan dalam artian makan bersama dimana semua makanan yang disajikan dibawa oleh masing-masing anggota atau keluarga.

Melalui bentuk-bentuk baru ibadah, Wesley coba membuat ibadah menjadi lebih penting bagi umat dan zaman. Perubahan-perubahan baru dalam kebaktian dari Wesley perlu diteliti secara lebih mendalam. Mungkin saja kebaktian-kebaktian ini terlampau cepat ditinggalkan.

Kebaktian Larut malam adalah suatu kebaktian yang dimulai jam 8 atau 9 malam dan berlangsung hingga tengah malam. Kebaktian ini yang tidak memiliki suatu tata cara yang tetap; mengandung doa, Khotbah dan bernyanyi. Kaum Moravia mempunyai suatu kebaktian yang mereka namakan Larut malam dan diadakan pada hari terakhir dari tahun. Tetapi Wesley, mengadakan kebaktian ini sekali dalam sebulan pada suatu Jumat malam yang terdekat dengan bulan purnama.

Motivasi Wesley untuk mengadakan kebaktian larut malam ini mungkin bersifat ganda. Ia ingin memberikan pengajaran Alkitab kepada kelompok-kelompok yang tidak dapat dia dekati, yaitu mereka yang telah menerima keselamatan, tetapi menghabiskan malam-malam penuh dengan minuman keras.

Kebaktian ini tidak pernah dijalankan secara meluas dan malah telah dihentikan sebelum dia meninggal. Seperti halnya Perjamuan Kasih, kebaktian ini juga tempaknya hanya digunakan untuk kebutuhan tertentu saja. Melalui bentuk-bentuk ibadah ini Wesley ingin mencapai sekelompok orangorang tertentu yang sulit ditemuinya dan memberikan suatu pilihan lain bagi orang-orang itu terhadap daya pikat rumah minum. Setelah rumah-rumah pertemuan didirikan, kebaktian-kebaktian itu tidak diperlukan lagi dan ditinggalkan. Kebaktian-kebaktian itu mengarah kepada suatu tujuan khusus pada saat-saat perkembangan Methodisme di Inggris. Ketika hal tersebut telah tercapai, Wesley meninggalkannya.

Dalam mengembangkan Kebaktian Perjanjian, Wesley mengambil dari berbagai macam tradisi. Ia mengambil konsep tersebut dari buku-buku Joseph Alleine, Call to the Unconverted dan Directions for Believers Covenanting with God. Selain itu dia juga mengambil dari tradisi Puritan. Baik Presbyterian dan Baptist, juga memiliki tradisi dalam perjanjian dan kebaktian perjanjian. Namun Wesley menyatakan, bahwa kebaktian ini didasarkan kebiasaan buku gereja kuno

Kebaktian Perjanjian tidak pernah menjadi suatu bagian dalam kebaktian Methodist Amerika. Ini bukanlah suatu kebiasaan dari Methodist Amerika awal. Discipline juga tidak memberikan petunjuk mengenai kebaktian ini. Uskup Matthew Simpson dalam Cyclopaedia of Methodism yang diterbitkan dalam tahun 1883 tidak menyebut suatu referensipun tentang diadakannya Kebaktian Perjanjian di Amerika dan menamakannya suatu kebiasaan "Wesleyan Inggris". Kita tidak tahu pasti mengapa orang Amerika tidak melakukan kebaktian ini. Wesley sendiri mengusulkan agar kebaktian ini dilakukan sekali dalam setahun, seperti yang sampai kini dilakukan oleh beberapa dari Kaum Methodist Inggris.

Dari ketiga bentuk ibadah yang diperkenalkan Wesley di Inggris, hanya Kebaktian Perjanjian yang meninggalkan pengaruhnya cukup lama. Kebaktian Perjanjian mengukuhkan suatu komitmen. Kebaktian tersebut menggabungkan dan menopang gereja sebagai suatu lembaga. Mungkin itu sebabnya hal ini masih terus dilanjutkan di Inggris.

Kegemarannya akan tata cara ibadah Anglikan dengan jelas dinyatakannya dalam kata pengantar dalam The Sunday Service of the Methodist in the United Sates of America: With Other Occasional Services - Kebaktian Hari Minggu dari Kaum Methodist di Amerika Serikat: Dengan Kebaktian Khusus Lainnya, yang ia kirimkan ke Amerika pada tahun 1784 yang menyatakan "Saya duga tidak ada liturgi di dunia ini, baik dalam bahasa kuno atau modern, yang bernapaskan lebih kokoh, Alkitabiah dan kesalehan yang masuk akal seperti yang terdapat dalam Common Prayer dari Gereja Inggris: dan walau bagian utamanya disusun lebih dari duaratus tahun yang lalu, juga diucapkan dalam bahasa yang bukan saja murni, tetapi kuat dan sangat anggun." Ia kemudian menyebutkan beberapa perubahan yang telah ia lakukan dengan menghilangkan sebagian dari hari- 
hari suci, menghilangkan beberapa kalimat dalam acara Baptisan dan penguburan orang mati, menghilangkan banyak mazmur-mazmur dan menyingkatkan waktu kebaktian Hari Tuhan. Sepanjang hidupnya ia menganjurkan pengikutnya untuk mengikuti kebaktian umum Gereja Inggris. Bahkan selama Revolusi Amerika, Wesley mendesak agar pengikutnya di Amerika mengikuti kebaktian umum di gereja-gereja Anglikan.

Tanpa mempedulikan anggapan orang Amerika, bahwa berbakti di gereja Anglikan merupakan pengkhianatan, Wesley menunjukkan kekhawatirannya atas sikap orang-orang Amerika dalam suatu komentar dalam catatan Inggrisnya: "Apa yang mereka lakukan di Amerika, atau apa yang dikatakan dalam catatan-catatan mereka mengenai hal ini, tidaklah berarti apa-apa bagi kami. Kita akan tetap melakukannya seperti cara lama yang baik. Dan jangan kita sekali-kali meremehkan untuk pergi ke gereja, baik dengan kata-kata ataupun tindakan."

Wesley berubah pendapat tentang beberapa hal yang berkenan dengan ibadah, tetapi dia tidak pernah mengubah sikapnya terhadap liturgi dari Gereja Inggris. Ia penuh dengan gagasan-gagasan baru baik didalam penggunaan dan pemahamannya akan kebaktian Anglikan dalam memperkenalkan bentuk-bentuk barunya dalam kebaktian.

Bagi Wesley liturgi Anglikan dan ibadah-ibadah lainnya dapat diterima hanya jika itu dapat memberikan keselamatan. Banyak penulis mencatat upaya Wesley untuk bahkan membuat Perjamuan Allah sebagai suatu upacara yang membawa keselamatan. Trevor Dearing menulis, misalnya, "Ekaristi adalah bagi Wesley, bukan saja suatu Upacara yang meneguhkan dan menyucikan, tetapi juga suatu cara penuh kasih yang menyelamatkan dimana para pendosa bertemu dengan Tuhan yang telah bangkit kembali dan mendapat kepastian akan penyelamatan diri mereka."

Sebagai kesimpulan, dapat kita katakan bahwa Wesley tidak pernah kehilangan kesetiaannya pada ibadah Anglikan. Ia meyakininya ini sejalan dengan kebiasaan-kebiasaan gereja kuno. Tetapi walau ia tidak mau menyimpang dari ibadah Anglikan, ia bersedia untuk memberikan tambahantambahan dan beberapa penghapusan. Ia menambahkan baik bentuk baru dari ibadah dan kebiasaankebiasaan baru dalam ibadah yang terdapat dalam Prayer Book. Tambahan-tambahan ini dibuatnya karena dirasa cocok untuk kebutuhan pekabaran Injilnya, dan Wesley menilai penemuannya menjadi dua kriteria: (1) Apakah mereka sejalan dengan kebiasaan-kebiasaan dari gereja kuno? Dan (2) Apakah ini memiliki kuasa untuk membawa keselamatan? Sikap Wesley terhadap ibadah sesuai dengan kebutuhan Amerika pada abad ke-18 dan 19.

\section{Aplikasinya}

Ibadah Methodist Amerika terbentuk atas dasar-dasar kuat yang diletakkan oleh John Wesley di Inggris. Dalam beberapa hal pendekatannya untuk beribadah malah lebih cocok untuk Amerika dibandingkan dengan tanah airnya di Inggris.

Apakah tradisi ini masih penting untuk masa kini? Tentunya tidak secara harfiah. Jemaat Methodist Modern akan sangat sulit menerima penggunaan Perjamuan Kasih seperti yang digunakan dalam abad ke-19 atau memberlakukan kembali penggunaan karcis masuk untuk mengikuti perjamuan kudus.

Namun ada cara-cara dimana tradisi dapat dan harus digunakan. Tradisi harus digunakan secara cermat dengan mengambil daripadanya hal-hal yang dapat bermanfaat bagi Ibadah di dalam suatu jemaat modern. Dengan kata lain, ibadah harusnya "diubah menurut keragaman dari Negara, waktu, tingkah laku orang-orangnya sehingga tidak ada yang ditetapkan yang melawan perintah Allah".

Penelitian kita terhadap sejarah ibadah di Amerika telah menunjukkan bahwa para Misionaris awal Methodist ke Amerika memiliki kepedulian ini. Mereka mencoba untuk memastikan bahwa 
kaum Methodist memberikan tekanan pada pentingnya menghormati tata cara ibadah yang telah berjalan. Wesley sangat menentang pada perubahan demi untuk merubah. Ia tidak ingin bahwa ibadah menjadi menarik hanya karena ini sesuatu yang baru dan berbeda. Setiap perubahan yang dibuat Wesley didalam isi dari Common Prayer Book /Buku Doa Umum yang telah disederhanakan dibuat karena bersifat praktis, atau didalam banyak hal, mengandung pertimbangan teologis. Fokus dalam Gereja Methodist adalah hasil dari ibadah itu sendiri dan bukan pada peristiwa atau tindakan ibadah itu saja. (Karen B.Westerfield Tucker, American Methodist Worship (Oxford: OXFORD UNIVERSITY PRESS, 2011)hal 14) Itu sebabnya pada akhir khotbah hampir selalu dilakukan "Altar Calling" yang dalam terjemahan Indonesia "Panggilan Kemuridan". Alkitab tetap merupakan kaidah tertinggi namun valid dan peraturan-peraturan lain ada dibawahnya. Sedangkan tradisi (Ibadah) bagi John Wesley merupakan sesuatu yang juga penting dan berharga namun selektif. (cf.Ibid,hal 19). Perubahan-perubahan tidak pernah diberikan hanya untuk menyediakan sesuatu yang baru. Kadangkala ia hanya menerimanya dengan sangat lambat suatu tata cara baru karena ia menyadari bahwa tidak ada pilihan lain atau ia melihat bahwa ini jelas-jelas menguntungkan.

Sudah tentu kita tidak dapat kembali pada corak ibadah tradisional ini. Namun adalah penting bagi kita masa kini untuk peka pada tradisi mereka dan meyakini bahwa perubahan yang dibuat adalah untuk memperbaiki mutu ibadah, bukan hanya untuk merubahnya.

Ketiga, baik John Wesley maupun Methodist Amerika menyesuaikan Ibadah agar sesuai dengan kebutuhan mereka. Maksud dari kebaktian Methodist adalah untuk menyelamatkan jiwa dan memeliharanya agar tetap terselamatkan. Wesley menerima suatu kegiatan baru bilamana ia meyakini bahwa hal itu akan berguna.

Konfrerensi Methodist amat tegas didalam hal-hal yang berkenaan dengan doktrin tetapi sangat bebas dalam hal-hal berkenaan kegiatan ibadah. Hal ini jelas dari apa yang pernah terjadi. Seorang pendeta dengan gayanya yang tidak lumrah diperbolehkan untuk memimpin Ibadah selama ada kejelasan, bahwa ia berhasil. Dalam otobiografinya Joseph Tarkington, ia menceritakan tentang seorang pendeta bernama Jonathan Shaw: "Gayanya adalah, ia berbicara dengan suara melengking, berjingkat tinggi diatas tumitnya, dengan kedua tangannya terbuka lebar dan kemudian ia tiba-tiba melipat tubuhnya, membungkuk, malah sampai duduk dan melompat dari satu ujung mimbar ke ujung lainnya dalam salah satu lompatannya, ia tergelincir dari mimbar itu dan terjatuh di lantai diatas tangan dan kakinya kepangkuan jemaatnya." Bahkan Tarkington tidak mencela cara berkhotbah yang tidak lazim itu.

Ibadah pada masa kini dapat menjadi sumber bagi pembaharuan Gereja - saat dimana orang diperhadapkan kenyataan hidup, lalu mereka pergi dengan janji-janji yang lebih mendalam dan pengabdian yang diperbaharui.

Perhatian yang sungguh-sungguh pada peran ibadah sebagai perangsang bagi pembaharuan Gereja. Kepekaan pada tradisi Ibadah Methodist juga membuka kemungkinan untuk menggunakan bentuk-bentuk ibadah seperti kebaktian Perjamuan Kasih atau Kebaktian Perjanjian untuk membantu orang-orang supaya menjadi lebih menyadari akan pengalamannya terhadap kenyataan dan menambahkan tingkat komitmen mereka.

Hubungan Ibadah dengan pengabaran Injil janganlah diabaikan, terutama bagi Methodist yang tradisinya memperlihatkan bahwa Allah menggunakan ibadah untuk membangkitkan kesadaran manusia terhadap dirinya. Peter Cartwright menggambarkan tentang "Pendeta keliling": "Dengan kumpulan buku-bukunya yang selalu menyertainya, yakni Kitab Injil, buku Nyanyian pujian dan disiplin. Ia mulai, dan dengan naskah yang tak pernah usang atau menjadi tidak menarik lagi, ia berseru: "Sesungguhnya domba Allah, yang menanggung dosa-dosa dunia." Pendeta keliling adalah seorang pengabar Injil.

Paul Sandres menggambarkan bawa pendeta-pendeta awal Methodist yang pekerjaannya adalah "berkhotbah dimana saja dan sesering mungkin, mengumpulkan mereka yang telah bertobat 
dan mereka yang mencari kebenaran untuk berkumpul dalam kelas-kelas kecil dan menjalankan suatu disiplin keimanan yang teguh didalam kelompok-kelompok ini. Khotbah-khotbah mereka bersifat estemporer/spontan, mengabarkan Injil dan penuh dengan emosi/perasaan."

Pekabaran Injil masa kini dapat dihidupkan kembali melalui khotbah-khotbah seperti yang dilakukan pada masa lalu. Suatu kebaktian dapat direncanakan sehingga dapat menjadi suatu pengalaman bagi mereka yang belum menyadari tentang pesan Injili. Ini dapat berarti, seperti yang diketemukan oleh Wesley, bahwa kebaktian Ibadah harus terjadi diluar dinding-dinding bangunan Gereja. Karena pekabaran Injil tidak selalu harus berarti mengumpulkan orang kedalam Gereja.

Situasi ibadah di Gereja Methodist menjelang abad 20 (1980 -1995) berusaha memperbaharui diri dari yang konservatif tradisional menuju ibadah kontemporer. Hal ini dapat dilihat minimal dengan adanya penggunaan alat musik di gereja dari hanya piano dan orgen kepada pemakaian alat musik lainnya seperti gitar dan alat musik lainnya. Malah sekitar tahun 2005 atau sebelumnya sudah biasa memakai alat musik "full band". Situasi ini tidak terlepas adari pengaruh gereja-gereja yang dikatakan sebagai "Gereja Kharismatik". Gereja ini memberikan suasana yang lebih meriah dan inovatif. Tidak dipungkiri gereja-gereja (Methodist) yang mengadopsi cara ini lebih disukai kalangan anak-anak muda. Mereka dapat mengekspresikan dirinya dalam ibadah tersebut. Lambat laun, mereka yang masih bertahan dalam ibadah tradisional mulai terbuka dengan melakukan inovasi. Misalnya ibadah dimulai dengan "Pujian dan Penyembahan" dipimpin oleh seorang "Worship Leader" lalu dilanjutkan dengan ibadah radisional sesuai dengan liturgi yang ada.

Bila diperhatikan liturgi-liturgi yang ada di kebanyakan gereja Methodist, sulit untuk melepaskan diri dari tradisi yang sudah ada. Kalaupun ada perubahan hanya sekedar "tambal-sulam" atau menambah asesoris di sana-sini. Makna perubahan itu sendiri belum terpikir dan terungkap dengan baik. Itu sebabnya sering didengar kesan "Ibadah di Gereja Methodist Indonesia (GMI) kurang menarik". Benarkah demikian? Tentu ini membutuhkan penyelidikan dan analisa lebih lanjut. Terlepas dari benar atau tidaknya, tentu perlu ditanyakkan mengenai tujuan perubahan atau inovasi tersebut. Seperti diungkapkan di atas, perubahan ibadah bukan hanya sekedar untuk perubahan, melainkan apakah makna dari perubahan tersebut. Ibadah bukan untuk menyenangkan hati yang beribadah, melainkan menyenangkan hati Tuhan yang disembah. Di sisi lain, ibadah juga harus melibatkan perasaan yang beribadah, sebab dilakukan oleh manusia yang memiliki perasaan dengan segala latar belakangnya.

Situasi di Indonesia sekarang dengan wabah pandemi Covid-19 membuktikan, bahwa Gereja harus inovatif dalam beribadah. Tidak ada lagi ibadah dalam gedung gereja, Tidak ada lagi ibadahibadah dalam artian berkumpulnya umat dalam satu tempat. Gereja melakukan inovasi dalam ibadah online yang mungkin dulu tidak pernah terpikirkan. Bahkan di desa terpencil, gereja melakukan ibadah dengan peralatan tradisional "TOA" yang dipasang tinggi-tinggi agar semua jemaat dapat mendengar dari rumah masing-masing. Tetapi juga didengar oleh mereka yang belum percaya. Ini suatu kesempatan yang langka. Khotbah-khotbah yang di-upload di media massa, FB, twiter, instagram dan lainnya yang memungkinkan didengar oleh banyak orang. Tinggal bagaimana para pengkhotbah membuat itu agar dapat diserap tanpa menyinggung perasaan, melainkan mendatangkan kehausan untuk mendengarkan berita keselamatan dalam Kristus Yesus. Ibadah-ibadah dilakukan dalam bentuk baru.

Wabah Korona memang bahaya yang menantang, tetapi juga menjadi kesempatan. Kesempatan untuk bersaksi, kesempatan untuk menyatakan kasih kepada sesama bukan hanya melalui kata melainkan dengan tindakan nyata. Ibadah tradisionil harus ditinggalkan dan diganti dengan ibadah inovatif, sesuai dengan teknologi yang dimiliki. Dampak ibadah inovatif ini akan terlihat dalam rumah tangga dan masyarakat kemudian. 


\section{DAFTAR PUSTAKA}

Bedell, Kenneth., $\quad$ Worship in The Methodist Tradition. Nashville: Tidings, 1976

Dalmais, I H., $\quad$ Introduction to the Liturgy (transl). London: Geoffrey Chapman, 1961

Doughty, W.L., J John Wesley Preacher. London: The Ephworth Press, 1955

Garret, T.S., $\quad$ Christian Worship. London: Oxford University Press, 1961

Martin, R.P., $\quad$ Worship in The Early Church. Grand Rapids: W.B. Eerdmans Publishing Company,

The Worship of God. Grand Rapids: W.B. Eerdmans Publishing Company, 1984.

Tucker, Karen B.W., $\quad$ American Methodist Worship. Oxford: Oxford University Press, 2001

Underhill, Evelyn, $\quad$ Worship. London: Nisbet \& Co., 1948

Vickers, John A., $\quad$ John Wesley - The Founder of Methodism. Lougborogh: Ladybird Books Ltd, 1972

Paul Wesley Chicote, "Jhon and Charles Wesley; Selection from their writings and Hymn- Annotated \& Explained, 2013 